\title{
Zhombwe (Neorautanenia brachypus (Harms) C.A.Sm.) - A recent discovery for mitigating effects of drought on livestock in semi-arid areas of Southern Africa
}

\author{
C. Murungweni, J.A. Andersson, M.T. van \\ Wijk, I. Gwitira, and K.E. Giller
}

Research

\begin{abstract}
In semi-arid areas drought results in cattle death making people vulnerable to poverty. Drought conditions are set to increase as climate change is increasingly becoming an important threat to food security. In southern Africa, people recently discovered Neorautanenia brachypus (Harms) C.A.Sm., as an important medicinal feed that they now use to help cattle survive drought. $N$. brachypus was evaluated with the aim of providing scientific substantiation of peoples' claims by determining the extent of its use, feed and anthelmintic value, and the ecological characteristics that explain its distribution. Information on characteristics and use of $N$. brachypus was gathered from focus group discussions and a semi-quantitative survey that employed structured interviews with both closed and open questions. The results showed that $N$. brachypus is used during drought by $59 \%$ of cattle owners, $14.5 \%$ do not use it because they have alternative grazing, and $26.5 \%$ did not know it can be used as cattle feed. Feed value of $N$. brachypus was evaluated as well as the anthelmintic value in the feeding trials with cattle and goats. $N$. brachypus contains adequate nutrients to maintain ruminant livestock during a drought. Infected animals fed on $N$. brachypus ended with less strongyloid worm infection in small ruminants $(P<0.05)$ and in large ruminants $(P<0.01)$ similar to animals dosed with the conventional recommended drugs. In the natural environment, $N$. brachypus was more commonly found in eutric vertisols and chromic luvisols than in ferric arenosols and leptosols, more in open spaces than in closed forests and more in cultivated areas than in naturally vegetated areas. It grows in a range of different types of soils and management affects its abundance. Ethnobotanical studies can offer important options on adaptation of human livelihoods to climate change.
\end{abstract}

Introduction

The catastrophic two-year drought in southern Africa from 1991 to 1992 resulted in death of 1.03 million cattle in Zimbabwe alone, more than $23 \%$ of the national herd (Tobaiwa 1993). Semi-arid areas were the worst affected, for example, $75 \%$ of cattle in one ward (Matibi 11) of south-east lowveld of Zimbabwe, died during this period (Cumming 2005). During the drought, a local farmer in the south-east lowveld was surprised to see two of his cattle eat tubers of Neorautanenia brachypus (Harms) C.A.Sm. that were exposed by ploughing. Tubers of this shrubby legume, which is called zhombwe in Shona, are known locally to be poisonous and are used by some to harvest fish from dams. Pigs have been observed to develop serious health complications when they eat this tuber. Thus the farmer expected his cattle to die, but to his surprise they showed no signs of illness. Since no other feed was available, and cattle in the area were dying, the farmer dug up more tubers of $N$. brachypus and fed them to his

\section{Correspondence}

C. Murungweni, J.A. Andersson, M. T. van Wijk, \& K.E. Giller, Plant Production Systems, P.O. Box 430, 6700 AK Wageningen, THE NETHERLANDS.

Chrispen.Murungweni@gmail.com

C. Murungweni, Grasslands Research Institute, DR \& SS (Livestock Division), P. Bag 3701, Marondera, ZIMBABWE.

I. Gwitira, Geography Department, P. O. Box MP167, Mt. Pleasant, Harare, ZIMBABWE.

J.A. Andersson, CASS, University of Zimbabwe, P.O. Box MP167, Mt. Pleasant, Harare, ZIMBABWE.

M.T. van Wijk, International livestock Research Institute, Nairobi, KENYA.

Ethnobotany Research \& Applications 10:199-212 (2012)

Published: May 15, 2012

www.ethnobotanyjournal.org/vol10/i1547-3465-10-199.pdf 
other cattle. Only cattle he fed with the tubers survived the drought, and since then many more farmers started using $N$. brachypus as a feed during droughts. Livestock keepers reported that intestines of slaughtered animals fed on the tubers showed no signs of internal parasites in their dung contents. Such information from local people has been appraised by researchers to be valuable if properly structured (Scott \& Hewett 2008, Toledo et al. 2009).

Parasitic worms collectively referred to as helminths are common in cattle herds and their control using chemicals is recommended. Helminths is a general term applied to multi-cellular worms that can be divided into three forms, namely: Nematodes (e.g., strongyloid, pinworm, hookworm, ascaris and trichuris), Cestodes (e.g., tapeworms) and Trematodes (e.g., intestinal flukes). Parasitic infections, notably of nematodes, have little impact on cattle mortality especially in drier regions, but they have a high economic impact because they cause retarded growth, weight loss, disorder in fertility and loss in milk production (Loyacano et al. 2002). In recent years, resistance to broad spectrum anthelmintics has been of major concern in veterinary parasitology (Waller 1997). This resistance has been reported with products like benzimidazoles and macrocyclic lactones (e.g., Avermectin, Milbemycin) (Mejia et al. 2003, Suarez \& Cristel 2007) and Levamisol (Waller 1997). Alternative sources for making new anthelmintic are needed. To our knowledge the use of $N$. brachypus as an anthelmintic or as livestock feed has not been previously reported. This prompted us to investigate: 1) the use and characteristics of $N$. brachypus tubers, 2) its feed value and anthelminthic properties, and 3) its distribution in the natural environment using the south-east lowveld of Zimbabwe case study.

\section{Materials and Methods}

\section{The Study Area}

The south-east lowveld of Zimbabwe lies below $600 \mathrm{~m}$ above sea level. Rainfall is highly variable (CV of $35 \%$ ) with an annual average of $400 \mathrm{~mm}$ mainly falling between November and April, and only rare showers the rest of the year (Cumming 2005). The wooded savanna developed on fertile soils is referred to as 'sweet veld' because it remains nutritious and palatable for livestock throughout the long dry winter season. Veld is a term used to describe the savanna grasslands of southern Africa. The veld of south-east lowveld is described as 'Aristida-Dactyloctenium-Eragrostis other species grassveld' with a carrying capacity of 0.084 to 0.14 tropical livestock units per hectare. Common grasses are Aristida adscensionis L., Dactyloctenium giganteum B.S. Fisher \& Schweick., Eragrostis viscosa (Retz.) Trin., Chloris virgata Sw., and on deeper soils with more moisture Urochloa spp., Panicum spp., Cenchrus ciliaris L. and Digitaria spp. (Rattray 1957). Five wards (11 to 15) form the study area (Figure 1). Cultivation is concentrated on the northern part (Ward 11)(see Murungweni 2011); N. brachypus is commonly used around this area. Vegetation is denser on the west of Gonarezhou National Park and in Gonakudzingwa smallscale commercial farms (Ward 12).

Cattle occupy a central position in livelihoods in the semiarid regions of rural Africa, (Kinsey et al. 1998, Mavedzenge et al. 2008). In addition to problems of lack of water and feed during drought periods (Oba 2001), the transmission of diseases is common in areas close to wildlife, promoted by increased contact between cattle herds with wildlife around the remaining watering holes (Dragon et al. 1999, Foster 1993). Cattle exhibit annual live weight gains of $15 \mathrm{~kg}$ per ha in well-managed grazing systems, but the grass biomass disappears rapidly in drought years or when the start of the rainy season is delayed (Elliott \& Folkersten 1961, Sibanda 1984). The abundance of a variety of trees and shrubs with leaves and twigs relished by cattle, such as Colophospermum mopane (J. Kirk ex Benth.) J. Léonard (Mopane), Grewia monticola Sond. (Donkey berry), and species of Combretum and Acacia extends the availability of feed into the dry season. But during drought such options become limiting due to early and increased dependence on browse species. N. brachypus now provides hope as an important survival strategy by farmers to keep cattle alive until the next rainy season.

\section{Interviews with livestock keepers}

In order to understand how cattle farmers use $N$. brachypus, focus group discussions and a household survey were conducted (Appendixes 1,2). The focus group discussions involved two groups of cattle farmers. One group consisted of six household heads residing in Gonakudzingwa small-scale commercial farms, and the other comprised of nine heads of households in Chikombedzi communal area (Ward 11). In these focus group discussions, questions were asked relating to uses of $N$. brachypus, who uses it, how it is used and when it is used. Household surveys were part of a global survey on livelihood analysis $(n=156)$ conducted using a semi-structured questionnaire. Only responses from cattle farmers $(n=83)$ across the four rural wards (Wards 11, 13, 14 and 15) were used for our analysis. These interviews were meant to gain more insights and to quantify use of $N$. brachypus by local people.

\section{Determination of the feed and anthelmintic value of $N$. brachypus}

Tubers of $N$. brachypus were dug up in the Sengwe communal area, southeast lowveld of Zimbabwe and transported to Grasslands Research Institute, Marondera, Zimbabwe for analysis and use in feeding trials. The Grasslands Research Institute (18`11'S, 31 ${ }^{\circ} 30^{\prime} \mathrm{E}, 1200$ masl). has a mean annual rainfall from 600 to $900 \mathrm{~mm}$ with at least $80 \%$ falling between November and March. Mean maximum temperatures of $31.1^{\circ} \mathrm{C}$ occur in October and the mean minimum of $8.4^{\circ} \mathrm{C}$ in July. 
Murungweni et al. - Zhombwe (Neorautanenia brachypus (Harms) C.A. Sm.) - 201 Mitigating effects of drought in semi-arid areas of Southern Africa

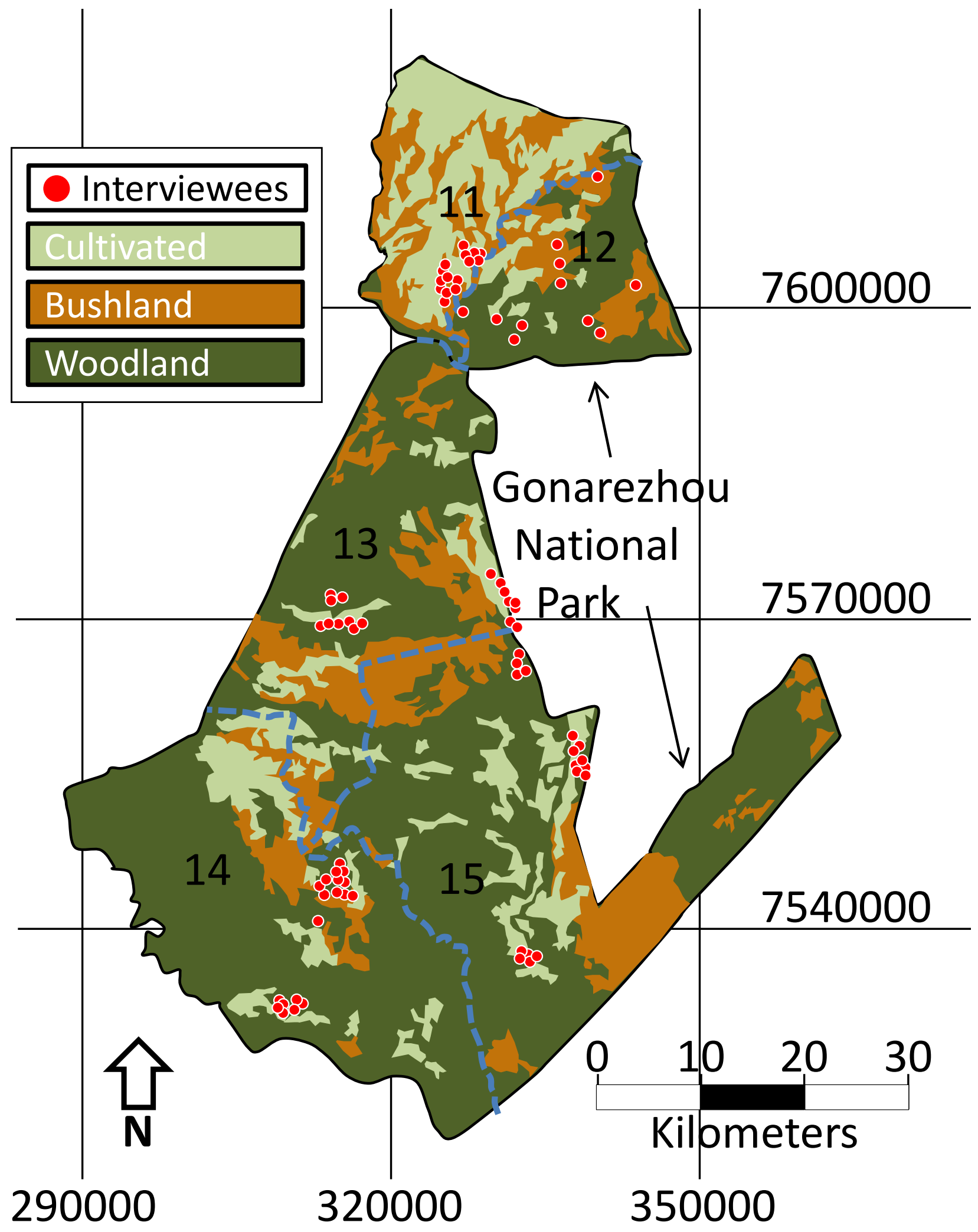

Figure 1. Landcover in Wards 11-15, Sengwe (Chiredzi district, south-east Zimbabwe) and location of households interviewed. Coordinates are in UTM zone 36 based on WGS 84 Spheroid. Ward 22 is Gonarezhou National Park. 


\section{Chemical composition of tubers}

Tubers were first peeled (i.e., farmers' practice) and cut into small slices to facilitate processing for analysis using standard methods (Heirich 1990). The water content was determined after oven drying fresh samples of eleven tubers randomly selected from 35 tubers dug out from different sites in the study area. Crude protein was determined as $6.25 \times$ total $\mathrm{N}$ using the Kjeldahl method (McDonald 1984). Cattle require diets containing at least $7 \%$ crude protein for maintenance and protein availability is particularly limiting in the veld during droughts. Crude fat was determined by Soxhlet extraction. Feeds with above $6 \%$ fat are likely to give some coating on the feed resulting in reduced digestion. Ground tuber samples were burned in a furnace at $600^{\circ} \mathrm{C}$ in order to determine the ash content. Neutral detergent fiber (NDF) and acid detergent fibre (ADF) were determined by the method of van Soest (Goering \& van Soest 1970). Digestibility was determined in vitro (Tilley \& Terry 1963) as described by Forejtova et al. (2005)

\section{Evaluation of the anthelmintic value of $N$. brachypus in goats}

Twelve female Boer goats were weighed and dipped before being randomly allocated to individual pens $(5 \times 3$ $\mathrm{m})$. Dung samples were collected from the rectum of each of the goats and analyzed for helminth loads (number of eggs/g of feces) using flotation and sedimentation methods. Helminth load was used to stratify individual goats into uniform groups before randomly assigning them to two treatments. The treatments were: 1 . The control treatment with six goats placed on a recommended drug treatment of Closavet (sodium closantel - a benzimidazole). These goats were fed a basal diet of $800 \mathrm{~g}$ hay of Cynodon nlemfuensis Vanderyst cv. No. 2 (9.5\% CP) ad libitum with free access to clean water. 2 . The test treatment with six goats feeding on $300 \mathrm{~g}$ of $N$. brachypus tuber on alternate days with the basal diet of $800 \mathrm{~g}$ hay of C. nlemfuensis. This was done to ensure that the goats received an adequate supply of roughage for proper rumen functioning. To encourage intake, goats on the tuber diet were initially given $300 \mathrm{~g}$ of $N$. brachypus and cottonseed cake in equal mixed proportions. The cottonseed cake was gradually replaced until the diet was solely 300 $\mathrm{g} N$. brachypus by the end of the week. Animals were fed once a day at $08.00 \mathrm{hrs}$. Daily feed intake was estimated by weighing refusals each morning before new feed for the day was weighed and offered. Dung samples were collected for analysis at the end of the trial after 30 days. Differences between treatments in helminth loads were tested using the non-parametric Mann-Whitney U Test.

\section{Evaluation of the anthelmintic value of $N$. brachypus in cattle}

Eighteen 13 month-old steers weighing $290 \pm 22 \mathrm{~kg}$ on average were dipped before being randomly allocated to individual pens $(10 \times 4 \mathrm{~m})$. Dung samples were collected from the rectum of each of the steers and analyzed for helminth loads (number of eggs/g of feces). Helminth load was used to stratify individual steers into three uniform groups and the members of each group randomly assigned to three treatment groups, each with six steers. These were then treated as: 1 . Control group not treated against helminths and fed a basal diet of hay of Hyparrhenia filipendula (Hochst.) Stapf (5.5\% CP) ad libitum, plus a protein supplement of $1 \mathrm{~kg}$ cottonseed cake $(40.2 \%$ CP). 2. Recommended drug treatment against helminths drenched with Rafasol (active ingredients rafoxanide 3\% $\mathrm{m} / \mathrm{v}$ and levamisole $3 \% \mathrm{~m} / \mathrm{v}$ ) and fed on the basal diet. 3 . $N$. brachypus treatment group fed tubers or the basal diet on alternate days. The tubers were initially chopped into $1 \mathrm{~cm}^{3}$ pieces but with time cattle ate 3 to $5 \mathrm{~cm}^{3}$ pieces. Intake was poor for the first few days but increased gradually from $2 \mathrm{~kg}$ per day to maximum of $6 \mathrm{~kg}$ fresh matter at the end of the second week. $N$. brachypus, hay and refusals were weighed, and new feed weighed and put into feeding troughs at $08.00 \mathrm{hrs}$ each day. Helminth loads were analyzed at the end of the trial.

\section{Distribution of $\mathbf{N}$. brachypus in the study area}

Sampling points at the center of a $5 \times 5 \mathrm{~km}$ grid generated by GIS were mapped across the whole $3,077 \mathrm{~km}^{2}$ area of Wards 11 to 15 bordering Gonarezhou National Park (Mabalauta sub-region). At the center of each grid square, $N$. brachypus plants in a $30 \times 30$ m quadrant were counted. Altitude, land use (crop field or natural veld) and vegetation cover in the quadrant were measured. A soil map of Zimbabwe was overlaid on the study area map in order to analyze if there were any differences in the abundance of $N$. brachypus between soil types. Analysis was done using the Kruskal Wallis test.

\section{Results}

\section{Neorautanenia brachypus and its uses}

N. brachypus, known locally as zhombwe by Shona speaking people who dominate Wards 11 and 12, and pombwe by Shangaan speaking people who dominate Wards 13 to 15, is now seen as a 'God-given life saver' (Mr. Zanamwe, Figure 2A). N. brachypus is a perennial, mostly erect herb or shrublet that produces purple flowers and pods (Figures 2B,C) on often trailing stems averaging $83.3 \mathrm{~cm}(\mathrm{SD}=14.5 \mathrm{~cm}), \mathrm{n}=35$. The underground tubers of 35 tubers had an average weight of $15 \mathrm{~kg}(S D=6.8 \mathrm{~kg})$, and 34 tubers had horizontal circumferences up to 86.4 $\mathrm{cm}(\mathrm{SD}=12.5 \mathrm{~cm})$. In eutric vertisols, large tubers (Figures 2D, E) can weigh up to $45 \mathrm{~kg}$. Traditional uses of $N$. brachypus are summarized in Table 1.

Livestock feeding is the major use in the south-east lowveld of Zimbabwe. The use of $N$. brachypus as a livestock feed began during the 1991-1992 drought and spread to other 


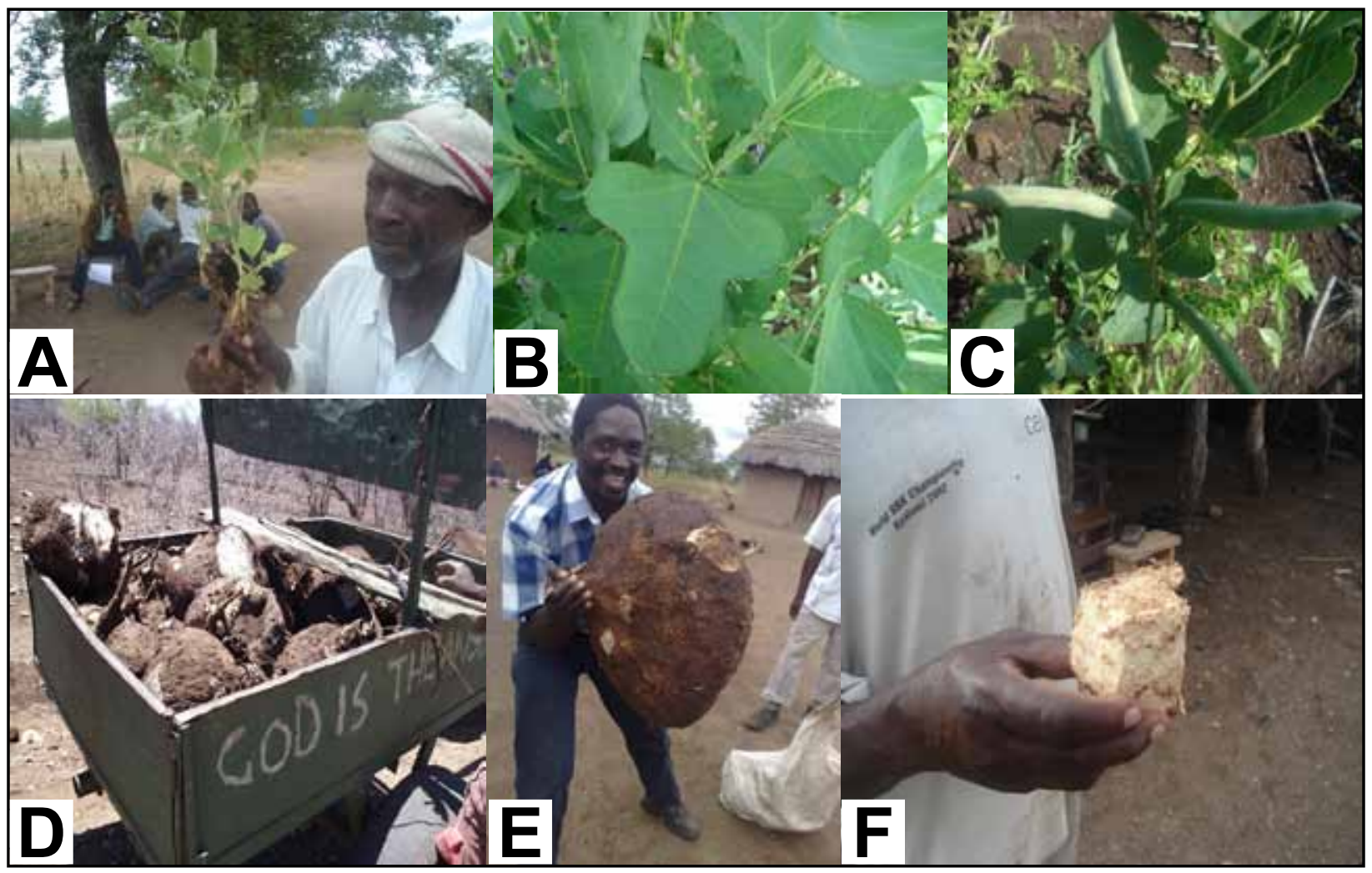

Figure 2. Neorautanenia brachypus (Harms) C.A.Sm. in the lowveld of Sengwe (Chiredzi district, south-east Zimbabwe). A) Mr. Zanamwe a farmer from Farm no.1 Gonakudzingwa elaborating on importance of $N$. brachypus that saved his 45 cattle during the 1997 drought. B) Leaves and flowers of $N$. brachypus. C) Pods of N. brachypus. D) An ox-cart full of harvested tubers. E) A large tuber. F) Size of tuber pieces fed to cattle.

Table 1. Uses and users of Neorautanenia brachypus (Harms) C.A.Sm., how and when the tuber is used in south-east lowveld of Zimbabwe.

\begin{tabular}{|c|c|c|}
\hline Uses & Cattle keepers in rural areas & $\begin{array}{l}\text { Cattle keepers in Gonakudzingwa small scale } \\
\text { commercial farms }\end{array}$ \\
\hline \multicolumn{3}{|c|}{ Output from focus group discussions } \\
\hline $\begin{array}{l}\text { Feeding } \\
\text { animals }\end{array}$ & $\begin{array}{l}\text { N. brachypus is commonly used during critical } \\
\text { feed shortages (e.g., during drought and during } \\
\text { dry season (especially August to October)). Dur- } \\
\text { ing April to July of the dry season, cattle feed on } \\
\text { dry leaves of Colophospermum mopane (J. Kirk } \\
\text { ex Benth.) J. Léonard. }\end{array}$ & $\begin{array}{l}\text { Only farmers with poor grazing in their farms } \\
\text { (Those farms on poorer soils) use } N \text {. brachypus } \\
\text { but only during critical droughts like in 1991-1992 } \\
\text { and } 1997 . \text { If there is a shortage of grazing during } \\
\text { dry seasons then they rent grazing in other com- } \\
\text { mercial farms with excess. }\end{array}$ \\
\hline $\begin{array}{l}\text { Dosing } \\
\text { animals }\end{array}$ & $\begin{array}{l}\text { Not a common practice, but some people dose } \\
\text { around February. Dosing before the rainy season } \\
\text { is not necessary because the cattle were feeding } \\
\text { on } N \text {. brachypus anyway. }\end{array}$ & $\begin{array}{l}\text { Common only during years of national economic } \\
\text { crisis when medicines are not available or are in- } \\
\text { accessible for example between } 2007 \text { and } 2010 \text {. }\end{array}$ \\
\hline $\begin{array}{l}\text { Treating } \\
\text { bad wounds }\end{array}$ & $\begin{array}{l}\text { Common practice now in the area bordering the } \\
\text { southern part of Gonarezhou Park. }\end{array}$ & Not a common practice, they buy medicines. \\
\hline $\begin{array}{l}\text { Harvesting } \\
\text { fish }\end{array}$ & $\begin{array}{l}\text { Not very common but few people do this. They cut } \\
\text { the tuber into small pieces and spread in pools of } \\
\text { water to stun fish for harvesting especially during } \\
\text { dry seasons and drought years. }\end{array}$ & $\begin{array}{l}\text { Not a common practice, they would rather kill an } \\
\text { impala or another small animal for food. }\end{array}$ \\
\hline
\end{tabular}




\begin{tabular}{|l|l|l|}
\hline Uses & Cattle keepers in rural areas & $\begin{array}{l}\text { Cattle keepers in Gonakudzingwa small scale } \\
\text { commercial farms }\end{array}$ \\
\hline Output from focus informal interviews with local people \\
\hline Habitat & $\begin{array}{l}\text { Most people interviewed said N. brachypus is found mainly in black soils that crack; more so in farmers' } \\
\text { fields than in grazing areas. We observed that only people in areas where grazing is in short supply } \\
\text { (e.g Ward 11, see Figure 1) had knowledge on use of N. brachypus as cattle feed. The extent of knowl- } \\
\text { edge on these uses decrease as we move from Chikombedzi (Ward 11) and Gonakudzingwa (Ward } \\
\text { 12) to Chibhavahlengwe (Ward 13) and upper part of Xini-Maose (Ward 15) which are somewhere in } \\
\text { the middle, to no knowledge at all in lower parts of Wards 14 and 15 close to Limpopo river }\end{array}$ \\
\hline Other uses & $\begin{array}{l}\text { Few people between the Limpopo River and Chikombedzi areas use N. brachypus for dosing cattle } \\
\text { only. Towards Limpopo river hunters use it to prepare a mixture (with food) and feed their dogs to im- } \\
\text { prove on their tracking abilities (interview with Mr. Mathosi of Sengwe ward 14) }\end{array}$ \\
\hline
\end{tabular}

areas afterwards, especially to areas with poor grazing. Of the 83 cattle farmers interviewed, $59 \%$ used $N$. brachypus during drought, $14.5 \%$ did not use it because they have alternative grazing and $26.5 \%$ did not know it could be used as cattle feed.

All farmers who use $N$. brachypus to feed their cattle during drought reported that animals feeding on the tubers can go without water for more days than when reliant on grass or browse. The joints of cattle feeding on the tubers are always strong despite the size of each individual. This means animals feeding on $N$. brachypus can walk relatively longer distances than others and can still pull a plough as some farmers explain. They also observed that animals feeding on $N$. brachypus produce dung that is thinner. They consider thinning of dung as helping to flush worms from the animals' guts and also helping digestion of dry and fibrous roughage when fed together. Farmers further observed that slaughtered animals that had been fed with the tubers had cleaner intestines, and worms were not seen
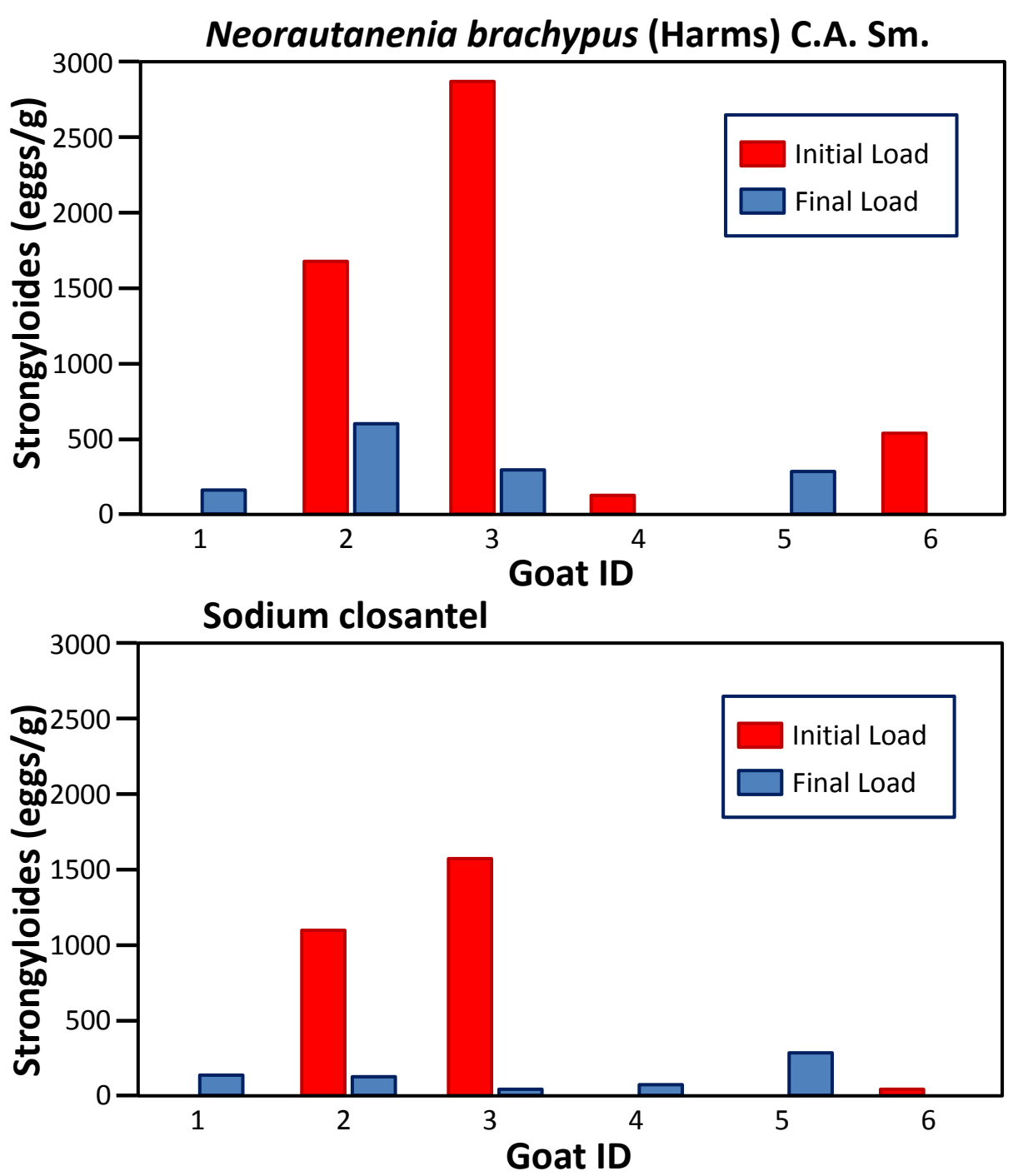

Figure 3. Load of intestinal strongyloid worms at the start and at the end of the goat feeding trial with Neorautanenia brachypus (Harms) C.A.Sm. and Closavet (sodium closantel) after 30 days. Interpretation of worm counts in goats: 0 to 100 (Good Result), 100 to 200 (considered low to drench), 200 to 500 (medium range, productivity loses and scouring), 500 to 1000 (High, production loses and scouring becoming significant), 1000 to 2000 (very high, some animals become anaemic), >2000 (too high, death may occur) 


\section{Murungweni et al. - Zhombwe (Neorautanenia brachypus (Harms) C.A. Sm.) - 205 Mitigating effects of drought in semi-arid areas of Southern Africa}

in their dung. Some farmers began experimenting with the tuber, they applied dry slices of the tubers to bad wounds on their animals and discovered that the wound remains clear of infection and heals rapidly. Negative effects were also observed, farmers say milking cows feeding on $N$. brachypus produce milk that does not turn sour as fast as they would expect, and the milk will not have the 'normal' milk taste.

\section{Chemical composition and digestibility of $N$. brachypus tubers}

The fleshy tuber of $N$. brachypus had a crude protein content of $104 \mathrm{~g} / \mathrm{kgDM}$. The water content of the tubers was $74 \%(S D=4.3 \%))(n=11)$. The NDF contents of the tubers of $241.5 \mathrm{~g} / \mathrm{kg} \mathrm{DM}$ was below the minimum expected mass fraction of $250 \mathrm{~g} / \mathrm{kg}$ DM whereas the ADF content of 192.4 $\mathrm{g} / \mathrm{kg}$ DM was above the minimum $160 \mathrm{~g} / \mathrm{kg}$ DM recommended for fiber in ruminant diets. The fat content of the tubers was low $(8.4 \mathrm{~g} / \mathrm{kg} \mathrm{DM})$ which is far below the maximum recommended $6 \%$ after which it can cause laxative effects during passage. Gross energy of the tubers was $17.3 \mathrm{~kJ} / \mathrm{g}$. Dry matter digestibility of the tubers was high at $83.1 \%(\mathrm{SD}=10.7 \%), \mathrm{n}=9$.

\section{Anthelmintic value of $\mathbf{N}$. Brachypus}

$N$. brachypus reduced the load of strongyloides in infected goats similar to dosing with Closavet $(z=1.3731$, not sig-

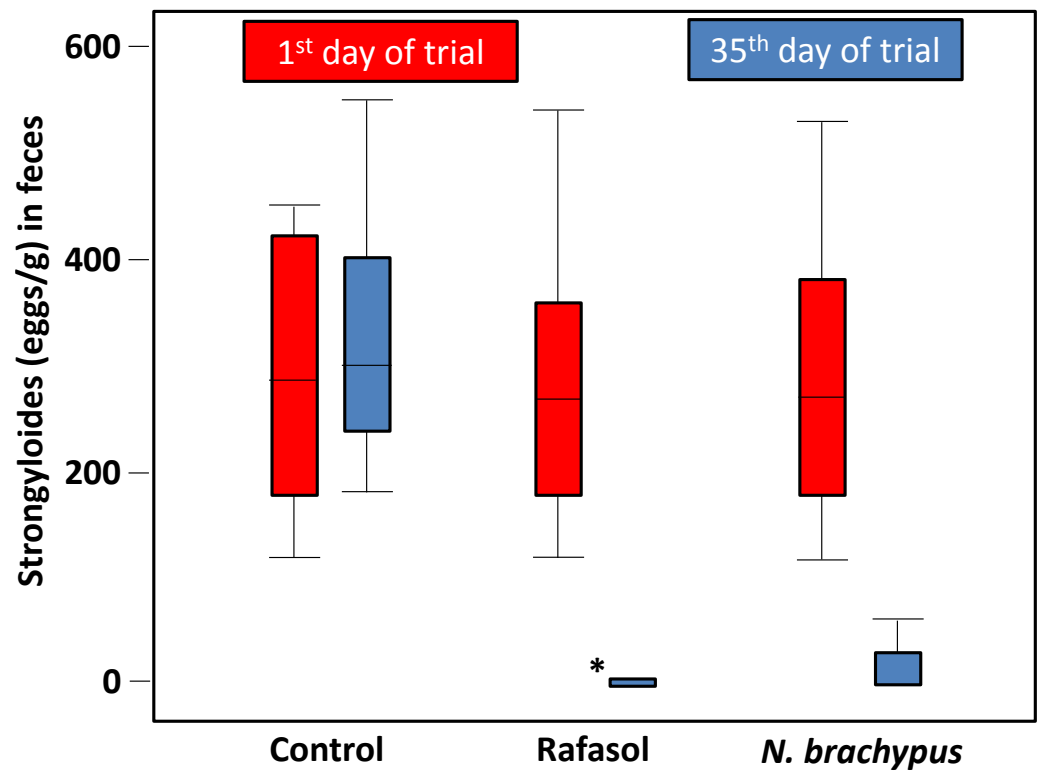

Figure 4. Load of intestinal strongyloid worms at the start and end of the cattle feeding trial after 35 days. Comparison of treatments with Rafasol (rafoxanide $3 \% \mathrm{~m} / \mathrm{v}$ and levamisole $3 \% \mathrm{~m} / \mathrm{v}$ ) or Neorautanenia brachypus (Harms) C.A.Sm. tuber. Interpretation of worm counts in cattle: 0 to 100 (Good Result), 100 to 200 (considered low to drench), 200 to 500 (Consider drenching), 500 to 700 (High levels, economic losses may occur), All animals should be drenched $>700$, mortality may occur if drenching is not done. nificant). Within one month, both Closavet and $N$. brachypus reduced the load of strongyloides in goats to an infection level below that likely to cause major economic losses (Figure 3). Similar results were observed with cattle where reduction in worm load of strongyloides resulted in different rank distributions across the three categories of treatment groups $\left(X^{2}=11.4, P<0.005\right)$. Reduction caused by $N$. brachypus in cattle was similar to that observed after dosing with the Rafasol (Figure 4).

\section{Distribution of $\mathbf{N}$. brachypus in the study area}

N. brachypus was not evenly distributed across the study area (Figure 5) raising the question in which habitats it is most commonly found.

We recorded more counts in eutric vertisols and chromic luvisols than in ferric arenosols and leptosols (Figure 6 ). N. brachypus was not observed in eutric fluvisols. No sampling was possible in eutric leptosols because of inaccessibility of the area. More counts were observed in crop fields than in the natural veld. It was also observed that $N$. brachypus can be propagated both by vegetative means and by seed. Its pods shatter when dry, thus cultivation may facilitate: 1 . covering the seed with soil during ploughing or weeding thereby facilitating germination, and 2 . splitting the tuber into many vegetative fragments that would act as new vegetative planting material. However, we observed that coarseness of soil negatively impacts number and size of $N$. brachypus tubers. Counts were observed to increase from rocky soils, through gravelly to 'normal' soils.

Farmers agreed that there is no clear indicator on the plant characteristics that can lead someone to say the tuber is large in size or small, but generally, they agree that there are better chances of getting a larger tuber in black soils that crack and more in cultivated or previously cultivated areas where the tuber is mostly found closer to the surface. Based on field observations, the size of these tubers did not relate to above ground height of plant.

\section{Discussion}

\section{Local uses of Neorautanenia brachypus}

$N$. brachypus has generated interest among cattle households in the southeast lowveld of Zimbabwe. Its feed and anthelmintic properties provide hope for surviving the negative effects of cli- 


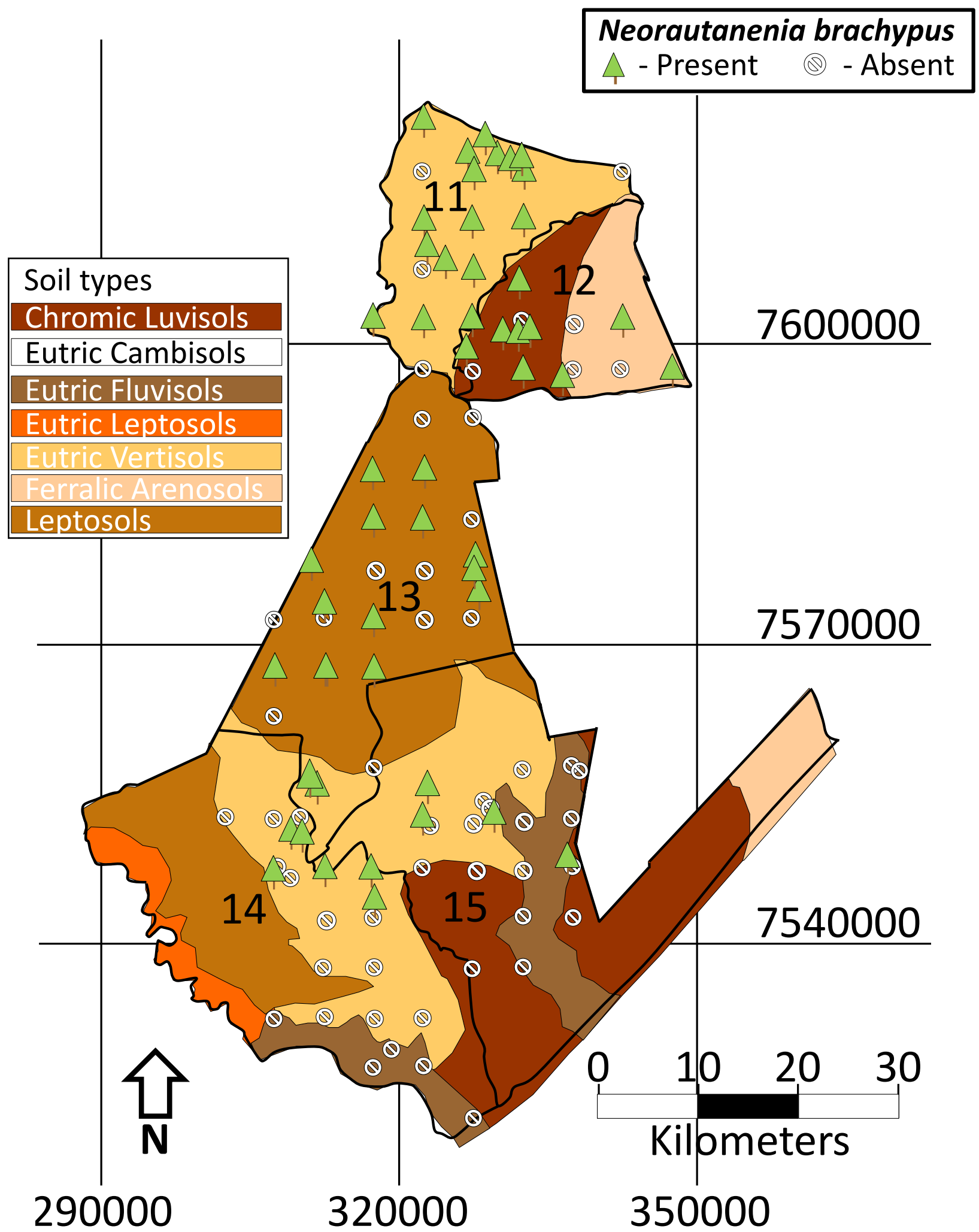

Figure 5. Distribution of Neorautanenia brachypus (Harms) C.A.Sm. in the Sengwe (Chiredzi district, south-east Zimbabwe) in relation to soil type. Coordinates are in UTM zone 36 based on WGS 84 Spheroid. Ward 22 is Gonarezhou National Park. 


\section{Murungweni et al. - Zhombwe (Neorautanenia brachypus (Harms) C.A. Sm.) - 207 Mitigating effects of drought in semi-arid areas of Southern Africa}

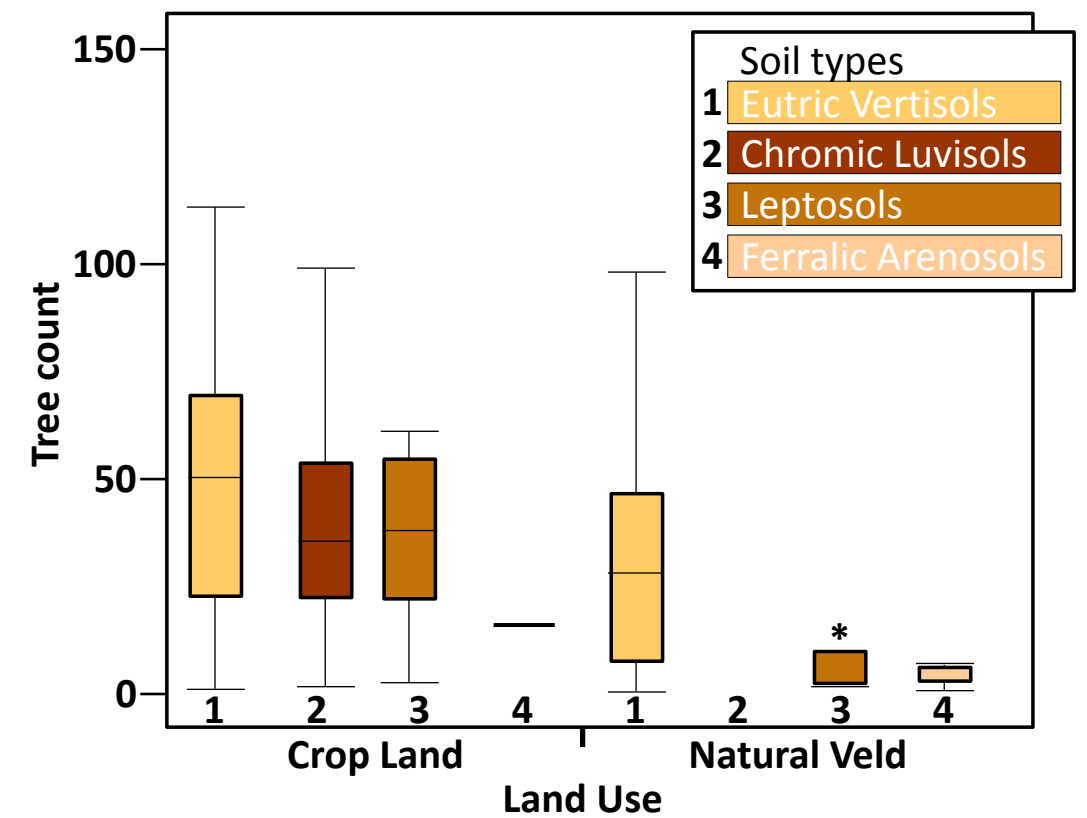

Figure 6. Counts of Neorautanenia brachypus (Harms) C.A.Sm. plants in 30 $\mathrm{m} \times 30 \mathrm{~m}$ quadrats within $5 \mathrm{~km} \times 5 \mathrm{~km}$ grid squares in natural veld $(\mathrm{n}=31)$ and cropland $(n=20)$ on different soil types in the lowveld of Sengwe (Chiredzi district, south-east Zimbabwe).

mate change on the food production system of semi-arid areas. After the initial discovery that $N$. brachypus can keep cattle alive during a drought, more farmers started harvesting tubers to save their cattle from death (see Figure 2D). The high water content of $N$. brachypus makes it suitable for drought feeding strategies. If animals eat 6 $\mathrm{kg}$ as in the controlled experiments, then the gross water content that they will receive is 4.4 liters. Based on field observations and interviews, farmers advised that once cattle become used to eating $N$. brachypus, they can eat even $20 \mathrm{~kg}$ of the tuber (about 15 liters of water). A livestock unit (an animal weighing $500 \mathrm{~kg}$ ) within an environment with temperatures above $27^{\circ} \mathrm{C}$, as is the case in south-east Zimbabwe, requires about 69 liters of water per day (ARC 1980). Considering that water requirements depend mainly on drymatter intake and temperature (National Research Council 1996), feeding tubers will reduce water requirements for cattle during drought. Presently, $N$. brachypus tubers are the sole diet for cattle in times of acute feed shortages (during periods of drought). Thinning of dung could be a result of the non-fibrous nature of $N$. brachypus when given as a sole dietary component. $N$. brachypus is low in NDF and ADF, the fiber content of diet.

\section{Feed and anthelminthic value of $\mathbf{N}$. brachypus}

The nutrient level of $N$. brachypus meets minimum nutrient requirements for maintenance of ruminant livestock. Livestock feed having protein content above $7 \%$ is adequate for maintenance (Topps \& Oliver 1993, Van Soest 1994). Dry matter digestibility was high, and is an impor- tant indicator of good nutritive value of the tuber (Forejtova et al. 2005). The tubers contain little fiber (NDF and ADF levels are low). NDF levels are negatively correlated to intake and ADF levels are negatively correlated to digestibility (Ball et al. 2007). The low intake at the beginning of the experiment can be explained possibly by experience of the animal to eating $N$. brachypus and period taken by the animal to adapt to the antinutritional factors found in $N$. brachypus. The detergent fiber contents do not limit usefulness of the tuber as a feed but low fibrous level suggests that $N$. brachypus should ideally not be solely fed to cattle in large quantities for many days without extra roughage, because poor fiber diets suppress rumen function and depress feed intake. However, farmers have no other option than to feed tubers as the sole feed at times especially in years of severe drought when no

forage is available. The strength possessed by animals fed $N$. brachypus could possibly result from anti-oxidant factors that require further investigation. Dragland et al. (2003) reported on several culinary and medicinal herbs that are important sources of dietary antioxidants and that phytochemicals result in health benefits. The thinning of dung observed by farmers could be a result of poor fiber levels of the tuber. Even though gross energy value has little direct significance in ruminant livestock feeding systems, gross energy value is an important starting point for estimating useful energy indices used in ruminant nutrition studies (digestible energy, metabolizable energy, and net energy). High digestibility value of the tuber gives an indication that its energy content could be used with high efficiency as the nutrients move along the digestive tract. The low fat levels have no negative consequences when fed in compound diets.

The effects of $N$. brachypus on strongyloides may suggest the clean intestines that farmers observe after slaughtering cattle previously on $N$. brachypus diet. These findings confirm claims by local people that the tubers of $N$. brachypus contain chemical compounds that are effective in deworming ruminant livestock. Worm infestation in livestock causes poor condition and economic losses resulting from weight loss, milk production loss and reduced fertility. Usually deworming should be done according to the advise by veterinary doctors but a routine programme of dosing livestock is recommended in Zimbabwe. Deworming should be done before rainy-season i.e. in mid-November (for the elimination of adult worms to reduce summer infestation), during mid summer, i.e., 
mid-January and at the end of the rainy season (just before winter during early April). Due to the lack of veterinary medicines for smallholders, infestation with intestinal parasites remains a major problem for cattle keepers. Further work is required to identify the active compounds making $N$. brachypus a strong antihelmintic against strongyloides, as well as how this active compound affects other types of helminths. $N$. brachypus could make an important contribution to the development or modification of a broad spectrum antihelmintics in an industry that is faced with development of widespread resistance.

\section{Distribution of $\mathbf{N}$. brachypus in the study area}

Information derived in this section is expected to add value to the biosystematics of $N$. brachypus, as such knowledge is needed for exploring commercial opportunities (Van Wyk 1996). In principle, N. brachypus can grow in different soils but soil type and management affect its abundance. This finding suggests that it would be possible to grow $N$. brachypus on a commercial basis. $N$. brachypus occurred more in eutric vertisols and chromic luvisols likely because these soils have weak structural properties that can facilitate expansion of tubers inside the soil during growth. Vertisols have unique properties of high clay content, volume changes with moisture, cracks that split and merge periodically, and evidence of soil movement in the form of slickensides (Özsoy \& Aksoy 2007). Chromic luvisols are characterized by a dark-colored A horizon of sandy clay loam texture underlain by a deep homogenous dusky red B horizon of clayey texture and are moderately well drained (International Soil Museum n.d.). Their macro structural development is mainly confined to the top soil and expressed as a weak medium sub-angular blocky structure with particle size distribution that indicates an increase in amount of clay corresponding to depth (Özsoy \& Aksoy 2007). Soils of loose structure and high nutrient content encourage growth of tubers. $N$. brachypus was observed in open spaces more than in closed areas. Open spaces are coincidentally areas with poor grazing and more cropping fields for example in Chikombedzi (Ward 11, Figure 1). In areas where grazing is problematic, excessive use of $N$. brachypus is expected, but the recruitment process makes it recover in time for the following season. The recruitment process is not properly understood and requires further investigation. To avoid over exploitation, cattle farmers in the south-east lowveld of Zimbabwe arrange with nearby small scale commercial farms (average land size $=750 \mathrm{ha}$ ) and rent grazing. More work is needed on growth characteristics of $N$. brachypus in order to test for other factors like altitude, irrigation, day length, temperature and fertilization and to check if this tuber can be cultivated.

\section{Conclusions}

Ethnobotanical studies continue to demonstrate how humans adapt to environmental changes by exploit- ing natural resources in novel ways. Whereas many ethnobotanical studies carried out at present demonstrate historically based human-plant relationships, this study shows how new and novel approaches of utilizing plants by indigenous communities continue to be discovered. $N$. brachypus has become an important medicinal feed in the southeast lowveld of Zimbabwe, which increases the resilience of household food systems to drought, providing an important adaptation of farmers to an increased drought threat due to climate change. In times of drought, farmers would rather keep their skinny animals alive than having cash from sales. Positive effects of $N$. brachypus include keeping cattle alive despite lack of forage, high water content of the tuber and medicinal properties of the tuber making it possible for farmers to dose their cattle as a dietary component. Plant characteristics that make $N$. brachypus useful include the ability to grow in different soils, forming an underground tuber, and its ability to propagate both vegetative and by seed. $N$. brachypus can be used most importantly as a survival feed during drought and to close the feed deficit gap during the dry season.

\section{Acknowledgements}

We thank the International Research and Education Fund (INREF) of Wageningen University for funding this research through the Competing Claims on Natural Resources programme (see www.competingclaims.nl). We are indebted to the people of Sengwe for providing us information on how they discovered the new use of Zhombwe for livestock feeding, Mr. Christopher Chapano (Harare Botanical Gardens) and Mr. Martin Brink and Prof. Phil Stevenson for assistance with identification of the tuber, and staff of Grasslands Research Institute for assisting with the field surveys and experiments.

\section{Literature Cited}

ARC. 1980. Agricultural Research Council. The Nutrient Requirements of Ruminant Livestock. Commonwealth Agricultural Bureau, Farnham Royal, Slough, UK.

Ball, D.M., C.S. Hoveland \& G.D. Lacefield. 2007. Southern Forages. 4th edition. Potash and Phosphate Institute and Foundation for Agronomic Research, Norcross, Georgia.

Cumming, D.H.M. 2005. Wildlife, livestock and food security in the South East Lowveld of Zimbabwe. Pp. 41-46 in Conservation and Development Interventions at the Wildlife/Livestock Interface: Implications for wildlife, livestock and human health. Edited by S.A. Osofsky, S. Cleaveland, W.B. Karesh, M.D. Kock, P.J. Nyhus \& A. Yang. IUCN, Gland, Switzerland.

Dragland, S., H. Senoo, K. Wake, K. Holte \& R. Blomhoff. 2003. Several culinary and medicinal herbs are impor- 


\section{Murungweni et al. - Zhombwe (Neorautanenia brachypus (Harms) C.A. Sm.) - 209 Mitigating effects of drought in semi-arid areas of Southern Africa}

tant sources of dietary antioxidants. Journal of Nutrition 133:1286-1290.

Dragon, D.C., B.T. Elkin, J.S. Nishi \& T.R. Ellsworth. 1999. A review of anthrax in Canada and implications for research on the disease in northern bison. Journal of Applied Microbiology 87:208-213.

Elliott, R.C.\& K. Folkersten. 1961. Seasonal changes in composition and yields of veld grass. Rhodesia Agricultural Journal 58:186-187.

Forejtova, J., F. Lad, J. Trinacty, M. Richter, L. Gruber, P. Dolezal, P. Homolka \& L. Pavelek. 2005. Comparison of organic matter digestibility determined by in vivo and in vitro methods. Czech Journal of Animal Science 50:47-53.

Foster, S. 1993. Maize production, drought and aids in Monze District, Zambia. Health Policy and Planning 8:247-254.

Goering, H.K. \& P.J. van Soest. 1970. Forage fiber analysis (apparatus, reagents, procedures and some applications). Pp. 1-20 in Agriculture Handbook No. 379. Agriculture Research Service. United States Department of Agriculture, Washington, DC.

Helrich, K. 1990. Association of Official Analytical Chemists. Pp. 1-19 in Official Methods of Analysis of the AOAC. 15th edition. Edited by K. Helrich. Association of Official Analytical Chemists Inc., Arlington, Virginia.

International Soil Museum. n.d. Chromic Luvisols Botswana Pp. 6-7 in Soil Monolith Paper No.1. International Institute for Aerial Survey and Earth Sciences (ITC), Enschede, The Netherlands.

Kinsey, B., K. Burger \& J.W. Gunning. 1998. Coping with drought in Zimbabwe: Survey evidence on responses of rural households to risk. World Development 26(1):89110.

Loyacano, A.F., J.C. Williams, J. Gurie \& A.A. deRosa. 2002. Effect of gastrointestinal nematode and liver fluke infections on weight gain and reproductive performance of beef heifers. Veterinary Parasitology 107:227-234.

Mavedzenge, B.Z., J. Mahenehene, F. Murimbarimba, I. Scoones \& W. Wolmer. 2008. The dynamics of real markets: Cattle in Southern Zimbabwe following land reform. Development and Change 39:613-639.

McDonald, P., R.A. Edwards \& J.F.D. Greenhalgh. 1987. Animal Nutrition. 4th Edition. Longman Group (FE) Ltd, Hong Kong.

Mejia, M.E., B.M. Fernandez Igartua, E.E. Schmidt \& J. Cabaret. 2003. Multispecies and multiple anthelmintic resistance on cattle nematodes in a farm in Argentina: The beginning of high resistance? Veterinary Research 34:461-467.

Murungweni, C., M.T. van Wijk, J.A. Andersson, E.M.A. Smaling \& K.E. Giller. 2011. Application of fuzzy cognitive mapping in livelihood vulnerability analysis. Ecology \& Society 16:4.

National Research Council. 1996. Nutrient Requirements of Beef Cattle. 7th revised edition. National Academy Press, Washington, D.C.

Oba, G. 2001. The effect of multiple droughts on cattle in Obbu, Northern Kenya. Journal of Arid Environments 49:375-386.

Özsoy, G. \& E. Aksoy. 2007. Characterization, classification and agricultural usage of vertisols developed on neogen aged calcareous marl parent materials. Biology and Environmental Science 1:5-10.

Rattray, J.M. 1957. The grass and grass associations of southern Rhodesia. Rhodesia Agricultural Journal 54:197234.

Scott, G. \& M.L. Hewett. 2008. Pioneers in ethnopharmacology: The Dutch East India Company (VOC) at the Cape from 1650 to 1800. Journal of Ethnopharmacology 115:339-360.

Sibanda, S. 1984. Composition of diet selected from veld by steers fistulated at the oesophagus, and the bodymass changes of non-fistulated steers grazing the same paddocks. Zimbabwe Journal of Agricultural Research 22:105-107.

Suarez, V.H. \& S.L. Cristel. 2007. Anthelmintic resistance in cattle nematode in the western Pampeana Region of Argentina. Veterinary Parasitology 144:111-117.

Tilley, J.M.A. \& R.A. Terry. 1963. A two stage technique for the in vitro digestion of forage crops. British Grassland Society 18:104-111.

Tobaiwa, C. 1993. Zimbabwe: The response to the 1992 drought in the context of long-term development objectives. SADC Drought Management Seminar Country Assessment Paper, Harare.

Toledo, B.A., L. Galetto \& S. Colantonio. 2009. Ethnobotanical knowledge in rural communities of Cordoba (Argentina): The importance of cultural and biogeographical factors. Ethnobiology and Ethnomedicine 5:40.

Topps, J.H. \& J. Oliver. 1993. Animal Foods of Central Africa. Revised edition. Modern Farming Publications Printing Division, Harare. 
Van Soest, P.J. 1994. Nutritional Ecology of the Ruminant. 2nd edition. Cornell University Press, Ithaca. New York.

Van Wyk, B.E. 1996. Priorities for biosystematic studies of the southern African flora. South African Journal of Science 92:327-329.
Waller, P.J. 1997. Anthelmintic resistance. Veterinary Parasitology 72:391-412. 


\section{Murungweni et al. - Zhombwe (Neorautanenia brachypus (Harms) C.A. Sm.) - 211 Mitigating effects of drought in semi-arid areas of Southern Africa}

Appendix 1. Questionnaire for determining presence and use of Zhombwe (Neorautanenia brachypus (Harms) C.A.Sm.) by cattle farmers in south-east Zimbabwe as determined through semi-structured interviews.

GPS Coordinates: $\mathrm{X}$ ,$Y$

Household name:

Village:

Ward:

Date:

Name of Interviewer:

1. How do cattle farmers cope with drought effects on livestock?

2. Is Zhombwe known by most people in Sengwe?

3. Where do you find Zhombwe? Why in those areas?

4. Who uses Zhombwe and for what reasons? Since when did people in this area start using Zhombwe for reasons mentioned? How was the discovery of Zhombwe for use as livestock feed happened?

5. Since when did people start using Zhombwe as livestock feed?

6. Which people use Zhombwe for livestock feeding?

7. Which classes of livestock are usually fed Zhombwe? Why those classes?

8. What 'abnormal' observations do people make on livestock fed Zhombwe?

9. When is Zhombwe used as cattle feed?

10. Any additional comments of interest on Zhombwe, its growth characteristics and value to people of Sengwe? 
Appendix 2. Data sheet for recording presence and use of Zhombwe (Neorautanenia brachypus (Harms) C.A.Sm.) by cattle farmers in south-east Zimbabwe as determined through semi-structured interviews.

\begin{tabular}{|c|c|c|c|c|c|c|c|c|c|c|c|c|c|c|c|}
\hline & & 2 & 3 & 4 & 5 & 6 & 7 & 8 & 9 & 10 & 11 & 12 & 13 & 14 & 15 \\
\hline $\mathbf{X}$ & $\mathbf{Y}$ & $\frac{0}{\frac{0}{\pi}}$ & 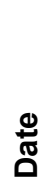 & 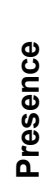 & $\begin{array}{l}\stackrel{0}{ \pm} \\
\overline{0} \\
\mathcal{O}\end{array}$ & $\begin{array}{l}\frac{1}{3} \\
\dot{\alpha}\end{array}$ & $\begin{array}{l}\frac{0}{0} \\
\frac{2}{20} \\
\frac{1}{4}\end{array}$ & 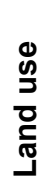 & 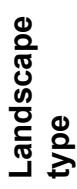 & 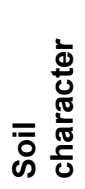 & 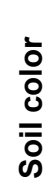 & 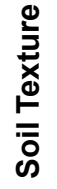 & 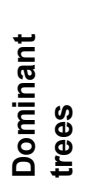 & 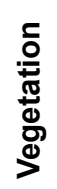 & 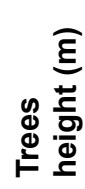 \\
\hline & & & & & & & & & & & & & & & \\
\hline
\end{tabular}

1. X: first GPS coordinate, Y: Second GPS coordinate (at the same point as X)

2. Ward: 11=Chikombedzi, 12=Gonakudzingwa, 13=Chibhavahlengwe, 14=Sengwe, 15=Xini/Maose

3. Date: Date when observation was made and sample collected

4. Presence: Whether Zhombwe is present or not $(1=$ No, $2=$ Yes $)$

5. Counts: Total number of Zhombwe plants counted at point of observation in $30 \mathrm{~m} \times 30 \mathrm{~m}$ quadrant

6. Av. Wt: Average weight of sampled tuber plants

7. Altitude: Height above sea level of point sampled

8. Land use: $1=$ crop field, $2=$ Natural veld

9. Landscape type: 1 = lowland flat, $2=$ Upland flat, 3= Upland slope, $4=$ Mountain top

10. Soil character: $1=$ Fine, $2=$ Rocky, 3=Stoney, $4=$ Gravelly

11. Soil Color: $1=$ light, $2=$ =black/dark, $3=$ red/reddish

12. Soil texture: 1=Sandy, 2=sandy-loam, 3=Loamy, 4=Clayey

13. Dominant trees: $1=$ Mopane, $2=$ Acacia, $3=$ Combretum, $4=$ Mixed, $5=$ Boza

14. Vegetation: 1=Continuous, 2=Scattered clustered, 3=Scattered isolated, Open

15. Tree height: $1=<3 \mathrm{~m}, 2=3$ to $5 \mathrm{~m}, 3=$ Above $5 \mathrm{~m}$ 